\title{
Cophylogeny and Biogeography of the Fungal Parasite Cyttaria and Its Host Nothofagus, Southern Beech
}

\section{Citation}

Peterson, Kristin R., Donald H. Pfister and Charles D. Bell. 2010. Cophylogeny and biogeography of the fungal parasite Cyttaria and its host Nothofagus, Southern Beech. Mycologia 102(6): 1417-1425.

\section{Published Version}

doi:10.3852/10-048

\section{Permanent link}

http://nrs.harvard.edu/urn-3:HUL.InstRepos:8954813

\section{Terms of Use}

This article was downloaded from Harvard University's DASH repository, and is made available under the terms and conditions applicable to Other Posted Material, as set forth at http:// nrs.harvard.edu/urn-3:HUL.InstRepos:dash.current.terms-of-use\#LAA

\section{Share Your Story}

The Harvard community has made this article openly available.

Please share how this access benefits you. Submit a story.

\section{Accessibility}


Mycologia, 102(6), 2010, pp. 1417-1425. DOI: 10.3852/10-048

(C) 2010 by The Mycological Society of America, Lawrence, KS 66044-8897

\section{Cophylogeny and biogeography of the fungal parasite Cyttaria and its host Nothofagus, southern beech}

\author{
Kristin R. Peterson ${ }^{1}$ \\ Donald H. Pfister \\ Department of Organismic and Evolutionary Biology, \\ Harvard University, 22 Divinity Avenue, Cambridge, \\ Massachusetts 02138 \\ Charles D. Bell \\ Department of Biological Sciences, University of New \\ Orleans, 2000 Lakeshore Drive, New Orleans, \\ Louisiana 70148
}

Abstract: The obligate, biotrophic association among species of the fungal genus Cyttaria and their hosts in the plant genus Nothofagus often is cited as a classic example of cophylogeny and is one of the few cases in which the biogeography of a fungus is commonly mentioned or included in biogeographic analyses. In this study molecular and morphological data are used to examine hypotheses regarding the cophylogeny and biogeography of the 12 species of Cyttaria and their hosts, the 11 species of Nothofagus subgenera Lophozonia and Nothofagus. Our results indicate highly significant overall cophylogenetic structure, despite the fact that the associations between species of Cyttaria and Nothofagus usually do not correspond in a simple one to one relationship. Two major lineages of Cyttaria are confined to a single Nothofagus subgenus, a specificity that might account for a minimum of two codivergences. We hypothesize other major codivergences. Numerous extinction also are assumed, as are an independent parasite divergence followed by host switching to account for $C$. berteroi. Considering the historical association of Cyttaria and Nothofagus, our hypothesis may support the vicariance hypothesis for the transAntarctic distribution between Australasian and South American species of Cyttaria species hosted by subgenus Lophozonia. It also supports the hypothesis of transoceanic long distance dispersal to account for the relatively recent relationship between Australian and New Zealand Cyttaria species, which we estimate to have occurred 44.6-28.5 mya. Thus the history of these organisms is not only a reflection of the breakup of Gondwana but also of other events that have contributed to the distributions of many other southern hemisphere plants and fungi.

Key words: Australasia, Leotiomycetes, long dis-

Submitted 2 Mar 2010; accepted for publication 22 Apr 2010

${ }^{1}$ Corresponding author. E-mail: krpeterson@ post.harvard.edu tance dispersal, South America, southern hemisphere, vicariance

\section{INTRODUCTION}

The obligate, biotrophic relationship between species belonging to the fungal genus Cyttaria (Ascomycota, Leotiomycetes) and their hosts in the plant genus Nothofagus (Hamamelididae, Nothofagaceae) has captured the attention of evolutionary biologists since Charles Darwin, whose South American collections of these fungi during the Beagle voyage became the first two Cyttaria species to be described (Berkeley 1842, Darwin 1839). After hearing from Joseph Dalton Hooker that a third Cyttaria species had been found in Tasmania, Darwin (1846) commented on the "singular relationship" between Cyttaria and Nothofagus in "distant parts of the world!"

The history of Nothofagus is considered to be important, even key, in understanding southern hemisphere biogeography (Cracraft 1975, Darlington 1965, Steenis 1971). Nothofagus pollen is distinctive, produced in copious amounts and is easily fossilized. First appearing by the early Campanian of the Late Cretaceous ( $~ 83.5$ mya) (Dettmann et al. 1990), its widespread, persistent, and abundant microfossil record, and to a lesser extent its macrofossil record, indicate that Nothofagus was widespread throughout much of southern Gondwana before continental breakup. In addition Nothofagus includes prominent forest trees that presently exhibit a widespread, disjunct southern hemisphere distribution, with modern representatives in South America (southwestern Argentina and Chile) and Australasia (southeastern Australia, New Zealand, New Guinea and New Caledonia) and with extinct taxa also known from Antarctica (Dettmann et al. 1990, Hill 1991). This disjunct, trans-Antarctic distribution, characterized by areas of endemism, traditionally is hypothesized to be entirely the result of vicariance and extinction because the dispersability of its seeds has been assumed to be insufficient to account for the distribution of Nothofagus species. The phylogeny of Nothofagus should be a reflection of the geological breakup sequence of southern Gondwana, according to this hypothesis. It is generally accepted that New Zealand was the first to separate $\sim 80$ mya and that South America and Australia were connected by Antarctica until $~ 35$ mya (McLoughlin 2001). Thus 
the phylogeny of Nothofagus should show that species from Australia and South America are more closely related to each other than to species from New Zealand (but see Giribet and Edgecombe 2006). However taxonomic arrangements and phylogenies of Nothofagus have inferred a closer relationship between Australian and New Zealand species (Dettmann et al. 1990, Hill and Jordan 1993, Hill and Read 1991, Linder and Crisp 1995, Manos 1997, Martin and Dowd 1993).

Nothofagus systematics. - Nothofagus comprises 35 extant species divided into four subgenera that correspond to pollen types (Dettmann et al. 1990, Hill and Jordan 1993, Hill and Read 1991): subgenus Brassospora (brassii type pollen) with 19 species in New Caledonia and New Guinea, which do not host Cyttaria species; subgenus Fuscospora (fusca type [a] pollen) with five species in southern South America and Australasia, which do not host Cyttaria species; subgenus Lophozonia (menziesii type pollen) with six species in southern South America and Australasia, all which host Cyttaria species; and subgenus Nothofagus (fusca type [b] pollen) with five species in South America, all which host Cyttaria species. Pollen types corresponding to the four modern subgenera first appear contemporaneously in the Antarctic fossil record in the late Campanian-early Maastrichtian of the Late Cretaceous ( 73 mya) (Dettmann et al. 1990). The monophyly of each of the four extant subgenera is supported by molecular sequence data (Martin and Dowd 1993, Setoguchi et al. 1997) and combined molecular and morphological data (Manos 1997). Nothofagus subgenera that host Cyttaria species, Lophozonia and Nothofagus do not together form a single monophyletic group (FIG. 1; Cook and Crisp 2005, Manos 1997, Martin and Dowd 1993, Setoguchi et al. 1997); of the extant subgenera Nothofagus is most closely related to Brassospora, representing the most recent divergence among subgenera, and subgenus Lophozonia is sister of the remaining three subgenera. Subgenus Lophozonia exhibits a disjunct trans-Antarctic distribution, with species occurring in Australia (including Tasmania), New Zealand and South America, while subgenus Nothofagus occurs only in South America. Thus modern day Nothofagus subgenera exhibit three trans-Antarctic relationships: within subgenus Fuscospora (with species from Tasmania and New Zealand more closely related to each other than to South American species), within subgenus Lophozonia (with species from Australia and New Zealand more closely related to each other than to South American species, and between subgenera Nothofagus (with species from South America) and Brasso- spora (with species from New Guinea and New Caledonia species).

Cyttaria systematics.-According to phylogenetic analyses of combined morphological and nuclear ribosomal RNA, mitochondrial ribosomal RNA and TEF1sequence data, genus Cyttaria comprises 12 taxa representing three major clades (FIG. 1; Peterson and Pfister 2010): one clade (A) occurs on subgenus Nothofagus, which occurs only in South America; the second (B) occurs only in South America on both subgenus Nothofagus and subgenus Lophozonia; and the third (C) exhibits a trans-Antarctic distribution, occurring in both South America and Australasia only on subgenus Lophozonia. In total seven Cyttaria taxa are endemic to southern South America (Argentina and Chile), on subgenera Lophozonia and Nothofagus, and the other five are endemic to southeastern Australasia and New Zealand on subgenus Lophozonia. Of the five Australasian taxa, two are found only in Australia, including Tasmania, and three are found only in New Zealand.

Associations between Cyttaria and Nothofagus.-Associations between species of Cyttaria and Nothofagus usually do not correspond in a simple one to one relationship; several Cyttaria species may infect the same Nothofagus species and a single Cyttaria species may infect several Nothofagus species (FIG. 1). Generally an individual Cyttaria species is associated with more than one (up to five) Nothofagus species, which in turn are associated with more than one (up to four) Cyttaria species. However hosts of Cyttaria species that are associated with multiple Nothofagus species invariably belong to the same subgenus (but see FIG. 1). Furthermore with the exception of one Cyttaria species each major Cyttaria clade is associated with a single Nothofagus subgenus. In no case is there a Cyttaria or Nothofagus species common to both South America and Australasia or between Australia and New Zealand. Despite extensive searching, Cyttaria has not been found on any of the Nothofagus species from New Caledonia or New Guinea (Korf 1983). It is unlikely that undiscovered species exist outside the current known range of Cyttaria. This is because of the conspicuous nature of the typical Cyttaria species, with its spherical, honeycombed fruit bodies (typically up to $4[-8] \mathrm{cm}$, depending on the species) (FIG. 2), usually obvious perennial cankers (depending on the species and type of canker produced, globose cankers up to $1 \mathrm{~m}$ diam on large branches and up to $1.5 \mathrm{~m}$ diam on large trunks, as well as longitudinal cankers of up to $1 \mathrm{~m}$ long) and often spectacular fruiting (up to 25 densely clustered fruit bodies in a single group and a carpet of fallen 


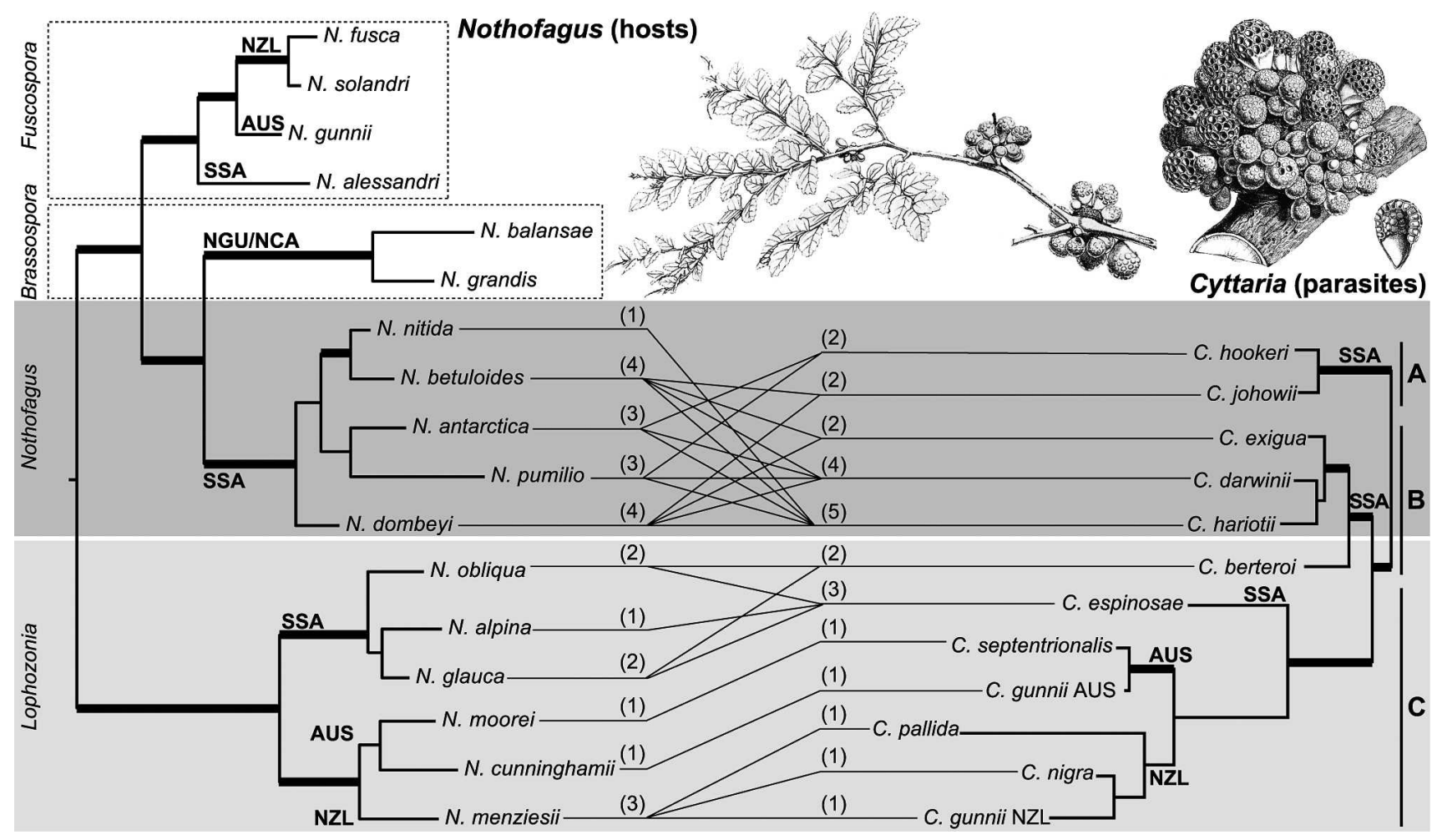

FIG. 1. Relationships between Nothofagus and Cyttaria. Branches in boldface are well supported ( $>0.95$ posterior probabilities or $>70 \%$ bootstrap proportion). Lines connecting hosts and parasites represent associations; numbers in parenthesis indicate number of associations per taxon. Shaded boxes indicate Nothofagus subgenera that host Cyttaria and the Cyttaria taxa associated with them. (Cyttaria clades A, B and C are discussed in the text and depicted in FIG. 2.) See Gamundí and Minter (2004a, b) and Peterson and Pfister (2010, TABle I) for reports of possible additional hosts $N$. dombeyi and $N$. obliqua for C. espinosae and C. hookeri respectively. Illustrations of C. gunnii and N. cunninghamii from Berkeley (1848) are reproduced courtesy of the library of the Gray Herbarium, Harvard University, Cambridge, Massachusetts. AUS = Australia, NCA $=$ New Caledonia, NGU $=$ New Guinea, NZL $=$ New Zealand, SSA $=$ southern South America.

fruit bodies up to $15 \mathrm{~cm}$ deep on the forest floor in one species).

Cyttaria species are presumed to be weak parasites (Gamundí and Lederkremer 1989) that produce trunk and branch cankers on Nothofagus trees. These cankers arise due to localized, stimulated cambial activity attributed to the presence of hyphae belonging to Cyttaria species, found in the secondary phloem and xylem, cambium and cortex of the hosts (Gutiérrez de Sanguinetti 1988, Wilson 1937).

Many have discussed the idea that parasites, including Cyttaria (Humphries et al. 1986, Korf 1983), can serve as taxonomists to elucidate relationships of their hosts. This idea implies that parasite and host phylogenies should be congruent or based on codivergence events. Confounding factors in this association relating to the parasite include host switching, extinction and speciation in the parasite lineage but not the host lineage. Especially problematic with respect to Cyttaria and Nothofagus is the fact that most Cyttaria parasites and Nothofagus hosts do not display a simple one to one correspondence. Also of interest is the occurrence of Cyttaria species on two relatively unrelated Nothofagus subgenera and their absence from the other two.

The relationship between Cyttaria and Nothofagus often is cited as a classic example of cophylogeny (e.g. Korf 1983) and is one of the few cases in which the biogeography of a fungus is commonly mentioned. Crisci et al. (1991), Seberg (1991), Linder and Crisp (1995) and Sanmartín and Ronquist (2004) included Cyttaria in their biogeographical analyses. Humphries et al. (1986) reconstructed five codivergence events, including the concurrent origins of Cyttaria and Nothofagus, which they inferred was significant cophylogeny in the associations between Cyttaria species and their Nothofagus hosts.

In this study we used molecular and morphological datasets derived from our work for Cyttaria (Peterson and Pfister 2010) and from Martin and Dowd (1993), Manos (1997) and Setoguchi (1997) for Nothofagus to test assertions of cophylogeny between the fungal 


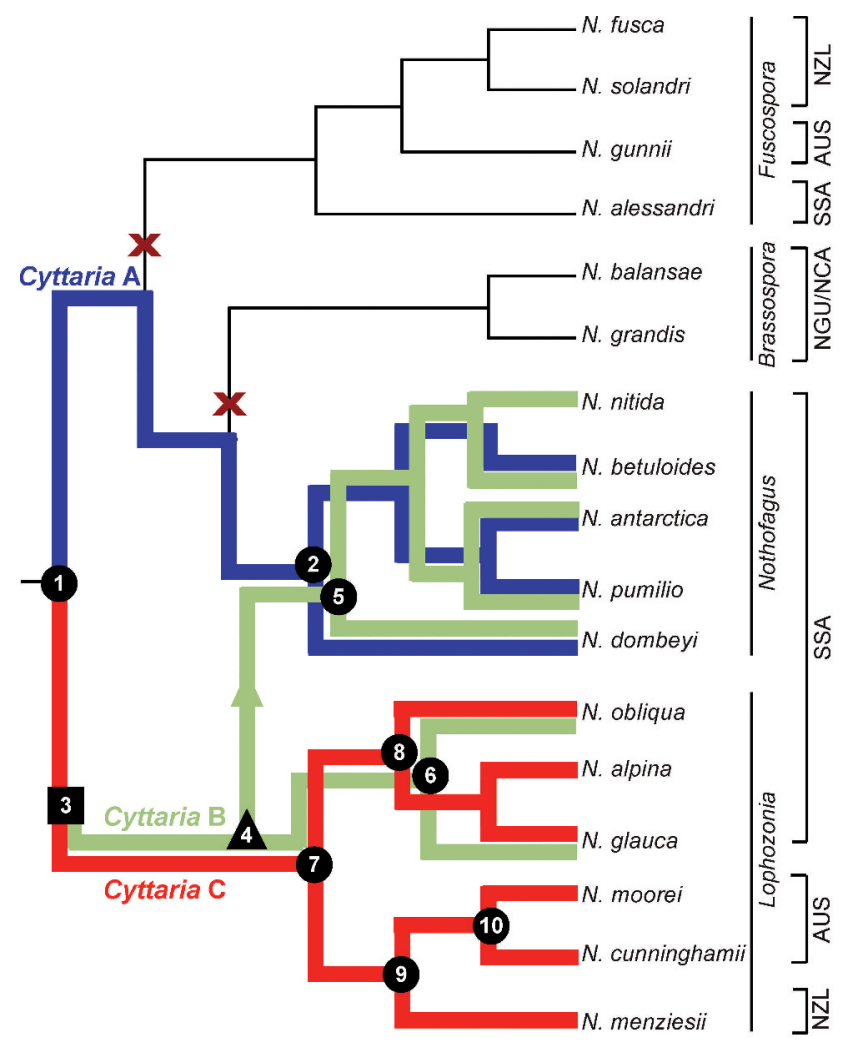

a.

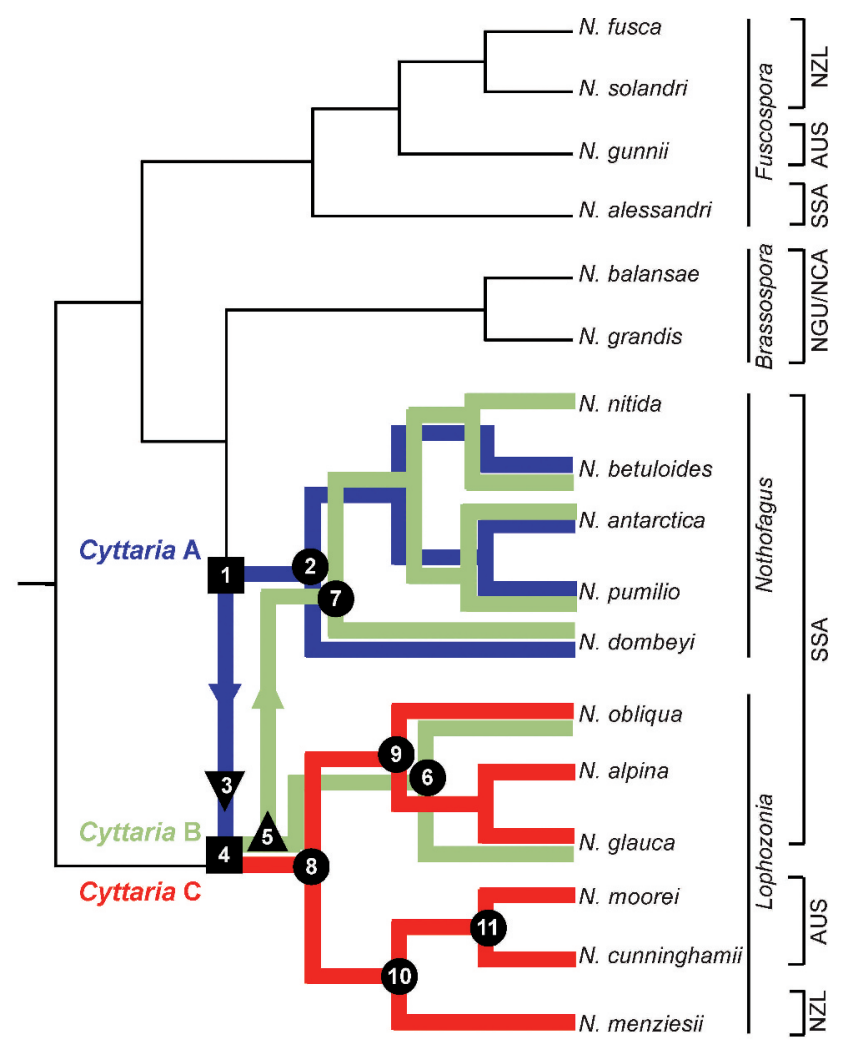

b.

FIG. 2. Hypothesized cophylogenetic reconstructions of Cyttaria taxa and Nothofagus hosts depicting major events. a. Represents the concurrent origin of Cyttaria and Nothofagus. b. Represents the colonization by Cyttaria after the origin of Nothofagus to explain the absence of Cyttaria on Nothofagus subgenera Brassospora and Fuscospora, which do not host Cyttaria. 5 s represent extinction or failure to track the host by Cyttaria. Events, labeled 1-10, are: circles, codivergence events; squares, duplication; and triangles, host switching. Cyttaria clades A, B and C represent the three major monophyletic lineages. AUS = Australia, NCA $=$ New Caledonia, NGU $=$ New Guinea, NZL = New Zealand, SSA $=$ southern South America.

parasite Cyttaria and its host plant Nothofagus. These results were used to examine the biogeographic history of Cyttaria.

\section{MATERIALS AND METHODS}

Parasite and host phylogenies.—Character alignments and GenBank sequences were obtained from studies on Cyttaria and Nothofagus. For Cyttaria an alignment of nuclear small subunit (nucSSU), nuclear large subunit (nucLSU), mitochondrial small subunit (mitSSU) ribosomal RNA (rRNA) and TEF1 sequence data as well as morphological data were obtained from our work (Peterson and Pfister 2010; GenBank EU107178-203, -205-232, -234-249). For Nothofagus alignments of chloroplast DNA (cpDNA) $r b c \mathrm{~L}$ sequences (Martin and Dowd 1993; GenBank L13341-345, $-348,-350-358,-360,-362)$, nuclear internal transcribed spacer (nucITS) rRNA sequences (Manos 1997; GenBank U96849-857, -859, -863, -865-870), cpDNA atpB-rbcL intergenic spacer sequences (Setoguchi et al. 1997; GenBank AF015687-690, -692, -696, -698-708) and morpholog- ical data (Manos 1997) were obtained from the original publications; the dataset of Knapp et al. (2005) was not used because it did not include all Nothofagus species that host Cyttaria. Seventeen Nothofagus representatives for which data were available for all four partitions were included. This included all Nothofagus species that host Cyttaria taxa, as well as select representatives from the other two Nothofagus subgenera. Methods for reconstructing phylogenies follow Peterson and Pfister (2010). Cyttaria phylogenies were taken from Peterson and Pfister (2010), where phylogenies resulting from the exclusion of morphological data also were considered.

Divergence time estimation.-Because the molecular data could be rejected as evolving in clock-like $(P<0.001)$, based on a likelihood ratio test, we used two relaxed clock dating methods: (i) penalized likelihood and (ii) an uncorrelated method implemented in BEAST 1.4.8 (Drummond and Rambaut 2007). An uncorrelated lognormal (UCLN) model implemented in BEAST was used to infer divergence times. Convergence of each chain to the target distribution was assessed with Tracer 1.4 (Rambaut and Drummond 2007) and by plotting time series of the $\log$ 
posterior probability of sampled parameter values. After convergence each chain was sampled every 1000 steps until 50000 samples were obtained. Model fit of the UCLN relaxed clock models was assessed with Bayes factors as implemented in Tracer 1.4. In addition divergence times were estimated with penalized likelihood (PL, Sanderson 2002) as implemented in the program r8s (Sanderson $2003)$. The optimal smoothing parameter $(\lambda)$ was determined by cross validation. We constructed confidence intervals for our PL based estimates with a bootstrap resampling technique (Baldwin and Sanderson 1998). First, the original dataset was resampled 1000 times with SEQBOOT 3.6 (Felsenstein 2005). Each replicate was used to re-estimate edge lengths on the optimal topology with ML in PAUP* 4.0b10 (Swofford 2002). Replicate trees were transformed in r8s and divergence time estimates summarized across trees with the PROFILE command.

Peterson and Pfister (2010, Fig. 1) was used to estimate divergence times relating to events pertaining to the Cyttaria clade. Paleopyrenomycites, widely regarded as the most important fungal fossil (e.g. Lücking et al. 2009, Taylor and Berbee 2006), was used to calibrate divergence among groups. It is uncertain to which fungal group this 400 myo fossil from the Rhynie Chert belongs. Taylor and Berbee (2006) regard it as an ancestral member of the Ascomycota, whereas Lücking et al. (2009) proposed it as an ancestral member of the Pezizomycotina. We therefore tested both hypotheses.

Host-parasite associations.-Data were taken from Calvelo and Gamundí (1999), Gamundí (1971) and Rawlings (1956).

Tree-based analyses of cophylogeny.-These methods take into account four basic types of cophylogenetic events: codivergence (cospeciation), duplication (independent speciation of the parasite), host switching and extinction; the latter is a type of loss, which also includes two other phenomena, missing the boat (failure to track all host lineages following a speciation) and sampling failure (failure of the researcher to observe parasites on their hosts); also confounding is the scenario in which parasites fail to diverge with their hosts (see review by Charleston and Perkins 2006). Based on the one host-one parasite assumption, these tree-based methods are unable to accommodate widespread parasites (parasites associated with more than one host); thus none were used in this study to calculate significance values. TreeMap (Charleston and Page 2002) however was used to provide a graphical depiction of hypothesized cophylogenetic events.

Distance-based analysis of cophylogeny.-COPYCAT (MeierKolthoff et al. 2007), a wrapper or interface for ParaFit (Legendre et al. 2002), was used to assess the null hypothesis of random association between parasites and hosts as performed in ParaFit. Host and parasite trees including branch lengths plus an association file representing all 25 parasite-host combinations (because most Cyttaria taxa are associated with more than one host) were input into COPYCAT, and tests of random association were performed with 9999 permutations globally across both phylogenies for each host-parasite association. Unlike earlier methods, ParaFit is able to accommodate any type of host-parasite association (Legendre et al. 2002), including widespread parasites (as well as trees with polytomies).

Data-based analysis of cophylogeny. - The incongruence length difference (ILD) test (Farris et al. 1995) was used to seek evidence that the Cyttaria and Nothofagus datasets were not samples of the same phylogenetic history. Complete parasite and host datasets were treated as partitions, such that each parasite-host pair consisted of a concatenation of all aligned data from a Cyttaria species and an associated Nothofagus host species. All 25 parasitehost taxa combinations were tested with 10000 replicates of the partition-homogeneity test in PAUP* 4.0b10 (Swofford 2002) with parsimony uninformative characters excluded.

\section{RESULTS}

Parasite and host phylogenies. - Cyttaria phylogeny (FIG. 1) recovered these notable clades are one composed of the South American species C. hookeri and C. johowii (A), which forms a monophyletic sister group with the remaining species, one composed of the South American species C. berteroi, C. darwinii, $C$. exigua and C. hariotii (B), which forms a monophyletic sister group with the remaining species, one composed of the South American species C. espinosae plus the Australasian species (C), a monophyletic Australian lineage and a monophyletic New Zealand lineage.

Nothofagus phylogeny (FIG. 1) recovered four monophyletic groups corresponding to subgenera in agreement with Manos (1997), Martin and Dowd (1993) and Setoguchi et al. (1997) and for the reduced set of taxa included here identical in topology to the combined consensus tree presented by Manos (1997). As indicated by earlier studies, the two subgenera that host Cyttaria, Lophozonia and Nothofagus, did not form a clade. Instead subgenus Lophozonia (Australia including Tasmania, New Zealand and South America), the designated outgroup in this study, was sister of the remaining subgenera. In this and previous studies the next to diverge, subgenus Fuscospora (Australia and Tasmania, New Zealand, and South America), was sister of the final two, subgenera Brassospora (New Caledonia and New Guinea) and Nothofagus (South America). Thus two subgenera, Fuscospora and Lophozonia, exhibit transAntarctic distributions. Furthermore subgenera Brassospora and Nothofagus together exhibit a third transAntarctic distribution.

Divergence time estimation.-Notable dates estimated for the Cyttaria lineage (TABLE I) include the origin of modern Cyttaria, estimated at 148.4-112.4 mya, the divergence between Australian and New Zealand 
TABLE I. Divergence estimates (mya) for key splits. BEAST ages represent the mean of the 95\% highest posterior density $(\mathrm{HPD})$. AUS = Australia, NZL = New Zealand

\begin{tabular}{lcccc}
\hline \hline & \multicolumn{1}{c}{ PL $^{\mathrm{a}}$} & BEAST $^{\mathrm{a}}$ & PL $^{\mathrm{b}}$ & BEAST $^{\mathrm{b}}$ \\
\hline Origin of Cyttaria & $112.2(101-123)$ & $112.4(64-157)$ & $148.4(133-162)$ & $146.3(84-178)$ \\
AUS/NZL split & $28.5(24-33)$ & $33.9(14-58)$ & $37.8(33-42)$ & $44.6(18-72)$ \\
C. espinosae split & $61.5(55-67)$ & $62.1(29-96)$ & $81.4(73-88)$ & $81.7(38-102)$ \\
C. berteroi split & $31.7(26-38)$ & $47.5(13-87)$ & $41.9(38-47)$ & $60.6(17-98)$ \\
\hline
\end{tabular}

${ }^{a}$ Fossil placed at the divergence of the Ascomycota.

${ }^{\mathrm{b}}$ Fossil placed at the divergence of the Pezizomycotina.

species estimated at 44.6-28.5 mya, the divergence of the clade that includes C. espinosae at 81.7-61.5 mya and the divergence of the clade that includes $C$. berteroi at 60.6-31.7 mya. With the exception of the divergence time estimate between the Australian and New Zealand species of Cyttaria, the two placements of the fossil Paleopyrenomycites produced times that were considerably older than geological and other events that would explain the divergences between these groups of Cyttaria. One example of this phenomenon may be that our estimates for the origin of Cyttaria predate the origin of Nothofagus, which has been estimated at 93-83.5 mya (Cook and Crisp 2005), and the origin of extant Nothofagus at 55-40 mya (Cook and Crisp 2005). These discrepancies at least in part likely are due to the problem of using a fossil far removed from our group of interest.

Distance-based analysis of cophylogeny. - The distancebased method ParaFit found highly significant overall cophylogenetic structure between the Nothofagus and Cyttaria datasets $(P<0.0001)$, regardless of correction method used in the DistPCoA setting (Lingoes, Cailliez, or no correction). Tests of individual links between host-parasite pairs found 23 (out of 25) links to be significant (significant $P$ values $=0.0001-0.03$ ) . The two nonsignificant links were those between $C$. berteroi and its two hosts.

Data-based analysis of cophylogeny. - The ILD test detected no significant difference between Cyttaria and Nothofagus datasets $(P=0.97)$. That is there was no evidence to indicate that they were not samples of the same phylogenetic history.

\section{DISCUSSION}

Cophylogeny between Cyttaria and Nothofagus.Analyses of cophylogeny (distance-based ParaFit and data-based ILD) indicate that Cyttaria taxa exhibit highly significant cophylogeny with Nothofagus hosts, even though associations between species of Cyttaria and Nothofagus usually do not correspond in a simple one to one relationship.
Parafit and ILD do not provide graphical depictions of probable cophylogenetic events. Given that both tests detected highly significant cophylogeny between Cyttaria and Nothofagus, we attempted to reconstruct their cophylogenetic history with TreeMap and present two possible, general scenarios (FIG. 2).

Cophylogeny scenario a.-Two Cyttaria lineages each are confined to a single Nothofagus subgenus (but see FIG. 1), a specificity that accounts for a minimum of two incidents of codivergence. Major incidents in the cophylogeny (events 1-10, Fig. 2a) are summarized: (i) an early codivergence at the concurrent origin of Cyttaria and extant Nothofagus leading to the South American subgenus Nothofagus hosting C. hookeri and C. johowii (Cyttaria clade A) and subgenus Lophozonia hosting the lineage that gave rise to all other Cyttaria taxa (Cyttaria clades B and C); (ii) a codivergence between the early diverging South American species C. hookeri and C. johowii (clade A) and their hosts in subgenus Nothofagus; (iii) a duplication (independent divergence) in the Cyttaria lineage on subgenus Lophozonia, which gave rise to (1) the South American C. espinosae plus all of the Australasian species (clade C) and (2) to the remaining Cyttaria species (clade B); (iv) host switching producing a dichotomy between the South American C. berteroi (clade B), which parasitizes subgenus Lophozonia, and the South American species C. darwinii, C. exigua and C. hariotii (clade B), which parasitize subgenus Nothofagus; (v) codivergence between C. darwinii, C. exigua, and C. hariotii (clade B) and their hosts, subgenus Nothofagus; (vi) codivergence between $C$. berteroi (clade B) and the South American lineage of subgenus Lophozonia; (vii) codivergence leading to the South American subgenus Lophozonia hosting $C$. espinosae (clade $\mathrm{C}$ ) and the Australasian subgenus Lophozonia hosting all Australasian members of Cyttaria (clade C); (viii) codivergence between $C$. espinosae (clade $\mathrm{C}$ ) and the South American subgenus Lophozonia; (ix) codivergence within the Australasian members of Cyttaria (clade C) and subgenus Lophozonia, giving rise to the Australian species and 
the New Zealand species; and (x) codivergence within Australian members of Cyttaria (clade C) and subgenus Lophozonia giving rise to C. gunnii sensu stricto and C. septentrionalis and respective hosts, $N$. cunninghamii and $N$. moorei. The absence of Cyttaria species on subgenera Brassospora and Fuscospora in this scenario is explained by extinction or missing the boat. If C. espinosae and C. hookeri also occur respectively on $N$. dombeyi and $N$. obliqua (see FIG. 1) two additional host-switching events also are inferred.

Cophylogeny scenario b.-This one (FIG. 2b) explains the absence of Cyttaria species on subgenera Brassospora and Fuscospora by inferring the infection of one clade of Nothofagus with a subsequent host jump to the other clade.

Biogeography of Cyttaria and Nothofagus.-Given fossil evidence that the four extant subgenera were widespread, occurring in Antarctica, Australia and South America before continental drift (Dettmann et al. 1990), vicariance resulting from the breakup of southern Gondwana comprise a plausible hypothesis to explain the three trans-Antarctic distributions exhibited by Nothofagus (FIGs. 1, 2). In support of this hypothesis a biogeographic reconstruction for Nothofagus by Sanmartín et al. (2007) inferred that these three Australasian-South American relationships (within subgenus Fuscospora, within subgenus Lophozonia and between subgenera Brassospora and Nothofagus) arose from vicariance. Knapp et al. (2005) estimated divergence at 65-36 mya between the Australasian and South American species of subgenus Fuscospora that were consistent with vicariance, but their results for the divergence between Australasian and South American species of subgenus Lophozonia were equivocal (38-21 mya, the lower point being too recent to be indicative of vicariance). In a similar study Cook and Crisp (2005) estimated divergence consistent with vicariance between the Australasian and South American species of subgenera Fuscospora at 45-30 mya and Lophozonia at 30 mya, as well as between Australasian subgenus Brassospora and South American subgenus Nothofagus at 4530 mya. Considering the historical association of Cyttaria and Nothofagus, the cophylogenetic reconstructions (FIG. 2) may support the vicariance hypothesis for the trans-Antarctic distribution between Australasian and South American Cyttaria species hosted by subgenus Lophozonia. The codivergence of one Lophozonia lineage with Australia and the other Lophozonia lineage with South America followed the divergence of their associated Cyttaria parasites. Our divergence estimates however are too early to support the vicariance hypothesis to explain the disjunction of
Cyttaria species in clade $\mathrm{C}$ present on subgenus Lophozonia, at 81.7-61.5 mya. The hypothesis of the presence of C. berteroi from clade B on subgenus Lophozonia being the result of host switching also is supported by our divergence estimates, at 60.631.7 mya, later than the divergence among $C$. espinosae and its Australasian relatives.

The riddle of Cyttaria. - Subgenus Nothofagus, which hosts Cyttaria, is sister of subgenus Brassospora, which does not host Cyttaria. Following Hill (1996), Swenson et al. (2001) discuss the riddle of the presence of subgenus Brassospora in New Caledonia and New Guinea. The riddle is its absence elsewhere, according to Heads (2006). Cyttaria presents a third riddle: Why is it present on subgenera Lophozonia and Nothofagus but absent on subgenera Brassospora and Fuscospora? The two subgenera that host Cyttaria are not sister taxa and they are not devoid of Cyttaria (FIGS. 1, 2). Furthermore, although the current distribution of subgenus Brassospora is restricted to tropical latitudes in New Caledonia and New Guinea, its species once were more widespread, occurring in Antarctica, Australia and South America by the late Maastrichtian (Dettmann et al. 1990). Subgenus Fuscospora, whose extant species co-occur with Cyttaria hosts in the other two subgenera, also was widespread, occurring in Antarctica, Australia and South America by at least the mid-Paleocene (Dettmann et al. 1990). In fact the four extant subgenera were distributed widely from Australasia to Antarctica and South America by the mid-Eocene (Dettmann et al. 1990).

With respect to subgenera Brassospora and Fuscospora the absence of Cyttaria remains a riddle. It is unknown whether the ancestors of subgenera Brassospora and Fuscospora simply escaped colonization by Cyttaria or whether Cyttaria went extinct on the ancestors of these subgenera. No fossils have been attributed to Cyttaria (Korf 1983), but if the fossil record of Nothofagus is any indication of what happened to Cyttaria extensive extinction likely contributed to the current distribution of Cyttaria. The biogeographic reconstructions by Linder and Crisp (1995) and Swenson et al. (2001), which predict extinct lineages within at least the three major lineages of Nothofagus (Fuscospora, Lophozonia and Brassospora-Nothofagus), demonstrate the effect of extinction on the interpretation of biogeographic patterns observed from extant species (see also Cook and Crisp 2005, Manos 1997).

Long distance dispersal from Australia to New Zealand.-In agreement with biogeographic, phylogenetic and taxonomic studies of Nothofagus (Cook and Crisp 2005, Dettmann et al. 1990, Hill and Jordan 
1993, Hill and Read 1991, Knapp et al. 2005, Linder and Crisp 1995, Manos 1997, Martin and Dowd 1993) and Cyttaria (Sanmartín and Ronquist 2004), this study found a closer relationship between Australian and New Zealand Cyttaria taxa (FIGs. 1, 2) associated with subgenus Lophozonia than would be predicted based on the breakup sequence of southern Gondwana. Some suggest that this common pattern is a result of propagules being carried by west wind drift, which began in conjunction with Antarctic circumpolar current ( $\sim 35-28$ mya), both of which could account for dispersal across the great expanse of the Tasman Sea (e.g. Sanmartín et al. 2007, Winkworth et al. 2002). The divergence between Australian and New Zealand species of extant subgenus Lophozonia was estimated by Cook and Crisp (2005) at 40-14 mya, and Knapp et al. (2005) estimated divergence at 3116 mya. Thus, according to this hypothesis, earlier Fuscospora and Lophozonia fossil pollen from New Zealand represent extinct lineages. Our divergence estimates infer the separation of Australian and New Zealand clades at 44.6-28.5 mya, consistent with the long distance dispersal of Cyttaria between Australia and New Zealand.

The fossil record suggests that several species of Nothofagus traveled from Australia to New Zealand via transoceanic long distance dispersal (Hill 2001; Pole 1994, 2001). Although all pollen types were present at some point in New Zealand, only one Nothofagus pollen type, now extinct, was present before New Zealand drifted from Gondwana, and representatives of subgenus Lophozonia, Australasian hosts of Cyttaria, did not appear in New Zealand until the Early Eocene (Dettmann et al. 1990).

Conclusions.-Because it was widespread in southern Gondwana before the drift of Australia, New Zealand and South America Nothofagus reflects the major events that occurred during the formation of the current biota of these regions, including vicariance, extinction and transoceanic long distance dispersal. This study demonstrates how, in turn, obligate associates of Nothofagus such as Cyttaria can function "sufficiently accurate as taxonomists" (Korf 1983) and perhaps hold keys to understanding more about their hosts.

\section{ACKNOWLEDGMENTS}

We thank three anonymous reviewers for comments on this manuscript. We thank M.J. Cafaro, G. Giribet and C.C. Davis for advice and comments on this project and manuscript. We also thank the library of the Gray Herbarium of Harvard University for permission to reproduce the Berkeley illustrations. We acknowledge financial support from the Department of Organismic and Evolutionary Biology of
Harvard University and the Fernald Fund of Harvard University Herbaria, as well as NSF PEET grant DEB9521944 to D.H. Pfister and M.J. Donoghue.

\section{LITERATURE CITED}

Baldwin B, Sanderson MJ. 1998. Age and rate of diversification of the Hawaiian silversword alliance. Proc Natl Acad Sci USA 95:9402-9406.

Berkeley MJ. 1842. On an edible fungus from Tierra del Fuego and allied Chilean species. Trans Linn Soc London 19:37-43.

. 1848. Decades of fungi: decade XX. London J Bot 7: 572-579, 1 plate.

Calvelo S, Gamundí I. 1999. The record of Cittaria exigua (Cyttariales, Ascomycetes) at Tierra del Fuego (Argentina). Hickenia 3:13-14.

Charleston MA, Page RDM. 2002. TreeMap (Jungle Edition). Version 2.0.2 (Beta). http://taxonomy. zoology.gla.ac.uk/\%7emac/treemap/index.html.

— and applications for cophylogenetic studies. J Biomed Inform 39:62-71.

Cook LG, Crisp MD. 2005. Not so ancient: The extant crown group of Nothofagus represents a post-Gondwanan radiation. Proc R Soc B 272:2535-2544.

Cracraft J. 1975. Historical biogeography and Earth history-perspectives for a future synthesis. Ann Mo Bot Garden 62:227-250.

Crisci JV, Cigliano MM, Morrone JJ, Roigjunent S. 1991. Historical biogeography of southern South America. Syst Zool 40:152-171.

Darlington PJ. 1965. Biogeography of the southern end of the world; distribution and history of far-southern life and land, with an assessment of continental drift. Cambridge, Massachusetts: Harvard Univ. Press. 236 p.

Darwin C. 1839. Journal of researches into the geology and natural history of the various countries visited by H.M.S. Beagle, under the command of Capt. Fitz Roy, R.N., from 1832 to 1836. London: Henry Colborn. $615 \mathrm{p}$.

- 1846. Journal of researches into the natural history and geology of the countries visited during the voyage of H.M.S. Beagle round the world. New York: Harper \& Bros. 675 p.

Dettmann ME, Pocknall DT, Romero EJ, Zamaloa MC. 1990. Nothofagidites Erdtman and Potonié, 1960: a catalogue of species with notes on the paleogeographic distribution of Nothofagus Bl. (southern beech). NZ Geol Survey Paleontol Bull 60:1-79.

Drummond AJ, Rambaut A. 2007. BEAST: Bayesian evolutionary analysis by sampling trees. BMC Evol Biol 7: 214-222.

Farris JS, Källersjö M, Kluge AG, Bult C. 1995. Testing significance of congruence. Cladistics 10:315-319.

Felsenstein J. 2005. SEQBOOT-bootstrap, jackknife or permutation resampling of molecular sequence, restriction site, gene frequency or character data. http:// wwwsacsucsfedu/phylip2/seqboothtml. 
Gamundí IJ. 1971. Las Cyttariales sudamericanas (FungiAscomycetes). Darwiniana 16:461-510.

—_, Lederkremer RM. 1989. Los hongos andinopatagonicos del genero Cyttaria. Sus hidratos de carbono. Cienc Investig 43:4-13.

- Minter DW. 2004a. Cyttaria espinosae. IMI Descript Fungi Bacteriol 160:1593.

—, 2004b. Cyttaria hookeri. IMI Descript Fungi Bacteriol 160:1597.

Giribet G, Edgecombe GD. 2006. The importance of looking at small-scale patterns when inferring Gondwanan biogeography: a case study of the centipede Paralamyctes (Chilopoda, Lithobiomorpha, Henicopidae). Biol J Linn Soc 89:65-78.

Gutiérrez de Sanguinetti MM. 1988. Exomorfologia y anatomia de los tumores en Nothofagus antarctica (Fagaceae) atribuidos a Cyttaria harioti y Cyttaria hookeri (Cyttariaceae). Symposio sobre Nothofagus (1987), An Acad Nac Cienc Exact Fis Nat 4:123-134.

Heads M. 2006. Panbiogeography of Nothofagus (Nothofagaceae): analysis of the main species massings. J Biogeogr 33:1066-1075.

Hill RS. 1991. Tertiary Nothofagus (Fagaceae) macrofossils from Tasmania and Antarctica and their bearing on the evolution of the genus. Bot J Linn Soc 105:73-112.

. 1996. The riddle of unique southern hemisphere Nothofagus on southwest Pacific islands: its challenge to biogeographers. In: Keast A, Miller SE, eds. The origin and evolution of Pacific island biotas, New Guinea to eastern Polynesia: patterns and processes. Amsterdam: SPB Academic. p 247-260.

- 2001. Biogeography, evolution and palaeoecology of Nothofagus (Nothofagaceae): the contribution of the fossil record. Aust J Bot 49:321-332.

—_ Jordan GJ. 1993. The evolutionary history of Nothofagus (Nothofagaceae). Aust Syst Bot 6:111-126.

- Read J. 1991. A revised infrageneric classification of Nothofagus (Fagaceae). Bot J Linn Soc 105:37-72.

Humphries CJ, Cox JM, Nielsen ES. 1986. Nothofagus and its parasites: a cladistic approach to coevolution. In: Stone AR, Hawksworth DL, eds. Coevolution and systematics. Oxford, UK: Clarendon Press. p 55-76.

Knapp M, Stockler K, Havell D, Delsuc F, Sebastiani F, Lockhart PJ. 2005. Relaxed molecular clock provides evidence for long-distance dispersal of Nothofagus (southern beech). PLoS Biol 3:38-43.

Korf RP. 1983. Cyttaria (Cyttariales): coevolution with Nothofagus, and evolutionary relationship to the Boedijnopezizeae (Pezizales, Sarcoscyphaceae). Aust J Bot Suppl 10:77-87.

Legendre P, Desdevises Y, Bazin E. 2002. A statistical test for host-parasite coevolution. Syst Biol 51:217-234.

Linder HP, Crisp MD. 1995. Nothofagus and Pacific biogeography. Cladistics 11:5-32.

Lücking R, Huhndorf S, Pfister DH, Rivas Plata E, Lumbsch HT. 2009. Fungi evolved right on track. Mycologia 101: 810-822.

Manos PS. 1997. Systematics of Nothofagus (Nothofagaceae) based on rDNA spacer sequences (ITS): taxonomic congruence with morphology and plastid sequences. Am J Bot 84:1137-1155.

Martin PG, Dowd JM. 1993. Using sequences of $r b c$ L to study phylogeny and biogeography of Nothofagus species. Aust Syst Bot 6:441-447.

McLoughlin S. 2001. The breakup history of Gondwana and its impact on pre-Cenozoic floristic provincialism. Aust J Bot 49:271-300.

Meier-Kolthoff JP, Auch AF, Huson DH, Göker M. 2007. COPYCAT: co-phylogenetic analysis tool. Bioinformatics 23:898-900.

Peterson KR, Pfister DH. 2010. Phylogeny of Cyttaria inferred from nuclear and mitochondrial sequence and morphological data. Mycologia 102:1398-1416.

Pole M. 1994. The New Zealand flora-entirely longdistance dispersal? J Biogeogr 21:625-635.

- 2001. Can long-distance dispersal be inferred from the New Zealand plant fossil record? Aust J Bot 49:357366.

Rambaut A, Drummond AJ. 2007. Tracer v1.4, available at http://beast.bio.ed.ac.uk/Tracer.

Rawlings GB. 1956. Australasian Cyttariaceae. Trans R Soc NZ 84:19-28.

Sanderson MJ. 2002. Estimating absolute rates of molecular evolution and divergence times: a penalized likelihood approach. Mol Biol Evol 19:101-109.

- 2003. r8s: inferring absolute rates of evolution and divergence times in the absence of a molecular clock. Bioinformatics 19:301-302.

Sanmartín I, Ronquist F. 2004. Southern hemisphere biogeography inferred by event-based models: plant versus animal patterns. Syst Biol 53:216-243.

- Wanntorp L, Winkworth RC. 2007. West wind drift revisited: testing for directional dispersal in the southern hemisphere using event-based tree fitting. J Biogeogr 34:398-416.

Seberg O. 1991. Biogeographic congruence in the South Pacific. Aust Syst Bot 4:127-136.

Setoguchi H, Ono M, Doi Y, Koyama H, Tsuda M. 1997. Molecular phylogeny of Nothofagus (Nothofagaceae) based on the $a t p \mathrm{~B}-r b c \mathrm{~L}$ intergenic spacer of the chloroplast DNA. J Plant Res 110:469-484.

Steenis CGGJ. 1971. Nothofagus, key genus of plant geography, in time and space, living and fossil, ecology and phylogeny. Blumea 19:65-98.

Swenson U, Backlund A, McLoughlin S, Hill RS. 2001. Nothofagus biogeography revisited with special emphasis on the enigmatic distribution of subgenus Brassospora in New Caledonia. Cladistics 17:28-47.

Swofford DL. 2002. PAUP*: phylogenetic analysis using parsimony (*and other methods). Version 4.0b10. Sunderland, Massachusetts: Sinauer Associates.

Taylor J, Berbee M. 2006. Dating divergences in the fungal tree of life: review and new analyses. Mycologia 98:838-849.

Wilson JM. 1937. The structure of galls formed by Cyttaria septentrionalis on Fagus moorei. Proc Linn Soc NSW 62: $1-8$.

Winkworth RC, Wagstaff SJ, Glenny D, Lockhart PJ. 2002. Plant dispersal NEWS from New Zealand. Trends Ecol Evol 17:514-520. 